\title{
Editorial. Small and Medium-sized Entities Reporting in Central and Eastern Europe
}

\author{
Cătălin Nicolae Albu ${ }^{\mathrm{a}, 1}$ and Karol Marek Klimczak ${ }^{\mathrm{b}}$ \\ ${ }^{a}$ Bucharest University of Economic Studies, Romania \\ ${ }^{a}$ University of Navarra, Spain
}

\begin{abstract}
This special issue of the journal of Accounting and Management Information Systems groups recent research into reporting by Small and Mediumsized Entities (SMEs) in four countries of Central and Eastern Europe (CEE), namely Poland, Romania, Slovenia and Turkey. SMEs represent the vast majority of entities in many jurisdictions around the world, contribute significantly to the economic development and employ a significant number of staff in their totality, despite overcoming sometimes severe difficulties in accessing funding, staffing or procuring resources to secure their survival and development. The editorial introduces the special issue by outlining the motivation that led to its publication, the common themes and the contribution of the papers presented, and by suggesting some future research avenues in light of recent developments. We strongly encourage our readers to discover the commonalities and differences that characterize the business and reporting environment of SMEs across the CEE region, as well as the diversity of approaches and practice existing in the region.
\end{abstract}

Keywords: SME, financial reporting, managerial accounting, CEE, European Union, Romania, Poland, Slovenia, Turkey

JEL codes: M13, M41, M48

\section{Introduction}

This special issue of the journal of Accounting and Management Information Systems (JAMIS) is dedicated to reporting by Small and Medium-sized Entities (SMEs) in Central and Eastern Europe (CEE). Against all odds (Ahrend \& Martins, 2003) SMEs constitute the powerhouse of European economic growth, accounting for more than 98\% of all business in the European Union (EU) (ACCA, 2012).

\footnotetext{
${ }^{1}$ Corresponding author: Cătălin Nicolae Albu, Bucharest University of Economic Studies, Piaţa Romană nr. 6, 010374, Bucureşti, Romania. Email: catalin.albu@cig.ase.ro
} 
Additionally, SMEs are the most dynamic sector of CEE countries. These countries, which account for approximately $20 \%$ of the EU's population, have been undergoing privatization and development processes that lead to an outburst of entrepreneurship. The importance of SMEs is recognized by the European Commission in the 2008 document titled the 'Small Business Act for Europe', calling for the promotion of entrepreneurship, the reduction of regulatory burdens, improved access to financing, greater internationalization for such entities and improved access to product markets (European Commission, 2008).

Professional accounting organizations worldwide recognize the potential contribution financial and management accounting can deliver to the effective functioning of SMEs. Notable topics considered include the internationalization of SMEs in CEE (ACCA, 2012); their corporate governance (ACCA, 2015) or management accounting practices and needs (CIMA, 2013); their accounting requirements (ICAEW, 2015); or their use of Small and Medium Practices (SMP) services (IFAC, 2016). Other professional bodies have issued a financial reporting framework for the use of SMEs (AICPA, 2013). Most professional bodies organize a distinct arm that deals with the challenges and issues pertaining to SMEs, or different events intended for such entities (such as the ACCA Global Forum for SMEs, organized by the Association of Chartered Certified Accountants - ACCA, the SME Conference organized by the Institute of Chartered Accountants in England and Wales-ICAEW, and a panel organized recently by the ICAEW during the $40^{\text {th }}$ annual congress of the European Accounting Association in Valencia).

This issue contributes to literature by collecting studies that tackle the evolutions and challenges of SME reporting from the diverse perspectives of countries in the CEE region. After the fall of communism around the early 1990s, the CEE region has provided 'unique societal quasi-experiments' where existing international business and management theories could be tested, and new theories could be developed (Meyer \& Peng, 2005). The academic literature provides some insights into the use of accounting by SMEs (Albu et al., 2013; Chau et al., 2013; Deaconu \& Cuzdriorean, 2016; Talpas, 2016; Tatoglu et al., 2016). Issues investigated so far include the financial reporting quality and the cost of debt of SMEs (Vander Bauwhede et al., 2015), the use of the International Financial Reporting Standard for SMEs (IFRS for SMEs) (Kaya \& Koch, 2015; Perera \& Chand, 2015), the alignment of accounting information systems in SMEs (Ismail \& King, 2007), the resource organization and SMEs performance (Andersén \& Samuelsson, 2016) or even the possible use of integrated reporting (Del Baldo, 2014). Studies point to the challenges that SMEs are facing when attempting to grow, survive or meet the expectations of their owner-managers, such as a limited or difficult access to customized funding, inadequate infrastructure, excessive reporting requirements, or the difficulties in securing adequate financial and non-financial resources to execute their strategies (Pissarides, 1999; Stoian et al., 2016). 
Beyond the already existing literature, the specific regional characteristics warrant further exploration. In fact, regional studies tend to be published in national languages, thus preventing the international research community from accessing up to date findings and from appreciating the diversity of approaches and practice existing in the region. This issue aims to increase the visibility of research conducted in the CEE countries and to support authors from the region in their efforts to internationalize their studies. Alongside earlier special issues of JAMIS (vol. 15(2), 14(2) and 13(2)), it forms a venue for the presentation of insights into the functioning of accounting in the region.

\section{Papers included in the special issue}

As indicated, the papers presented in this special issue detail the reporting experience of SMEs in Poland, Romania, Slovenia and Turkey.

Białek-Jaworska (2017) uses data from private Polish SMEs for 2003-2013 to look at the influence of bank borrowing on their book-tax conformity and accounting practices. Besides the book-tax differences measurement proposed by Watrin et al. (2014), the author applies Tang's (2015) approach to estimate a book-tax conformity measure that captures permanent and temporary book-tax differences, and finds that bank lending increases the book-tax conformity of profitable firms. Tax avoidance applied by borrowers has a lower impact on book-tax differential than in the case of non-borrowers. Moreover, findings indicate that monitoring by lenders force SMEs to adopt more advanced accounting practices by adhering to the prudence principle. The resulting increase in the informativeness of earnings allows lenders to learn more about the ability of borrowers to repay loans.

The second paper included in the special issue is Jerman (2017). The author gathers evidence on financial and management accounting by SMEs in Slovenia using regulation and regional academic sources. The paper contains a thorough review of regulatory requirements including national accounting standards and auditing requirements. Slovenia allows simplified accounting and tax treatment for SMEs, which is coupled with lax requirements for practicing accounting. Taxation being the main source of motivation for accounting, management accounting is not well developed, but the paper contains a review of survey results and academic literature devoted to the topic. Taken together, the paper contributes a systematic presentation of accounting in Slovenia.

The third paper included in the special issue is Cuzdriorean (2017). This is the only paper that deals specifically with SMEs' internal reporting practices (while the Jerman paper includes some research dedicated to such practices, but finds them to be underdeveloped). Given the financial and other constraints that SMEs generally face, they are less prone to adopt and use sound managerial accounting practices, 
making them more susceptible to corporate failure and growth problems. In this context, Cuzdriorean (2017) investigates the extent to which Romanian SMEs use traditional and more modern managerial accounting practices, by administering a survey to their owners and managers. The results suggest a reduced use of traditional techniques and a minimal use of the modern ones, confirming findings in prior literature. Budgeting, benchmarking and performance measurement seem to be in some demand in such entities, while the high costs of implementation, the lack of management commitment or financial constraints are the main reasons for the lack of use for certain managerial accounting techniques.

Next, K1lıc and Uyar (2017) contribute to the ongoing debate related to the possible adoption of the IFRS for SMEs in Turkey. Although IFRS for SMEs is still not required in this jurisdiction, Turkey was one of the first countries that have taken substantive steps towards the adoption of IFRS for SMEs. The authors interview Turkish accountants, academicians and auditors regarding the adoption process of IFRS for SMEs. The findings of the research confirm the need for a stand-alone standard set for SMEs. The interviewees asserted that a further simplification on IFRS for SMEs may hinder comparability of financial statements. While highquality financial information will be the most important advantage of applying IFRS for SMEs, cost burdens and the lack of trained personnel will be the major obstacles for the implementation process.

Finally, Waniak-Michalak (2017) discusses the advantages and drawbacks of using simplified statutory accounting by SMEs in Poland focusing on access to financing. While simplifications in both statutory and tax accounting offer cost benefits to the smallest companies, standard methods are used when employment numbers or capital expenditures are significant. Thus, the paper investigates whether simplified accounting hampers access to financing by reviewing bank offers and conducting interviews with bank officers. The results point towards a higher cost of financing as a consequence of using simplified accounting rather than reduced access to financing.

\section{Implications, calls for future research and conclusions}

This special issue will be of interest to academics following international developments in financial and management accounting by SMEs, as well as to professional bodies and practitioners. It is a rare example of a set of papers devoted to the CEE countries which would offer a thorough review of the accounting regulation and practice in the region. As the papers gathered in the special issue document, there exists a diversity in this region even though the countries share much in terms of economic transition and development. The papers bring evidence of the constraints SMEs are facing in the region in particular, and in other parts of the world in general, such as a difficult transition to the use of complex and modern 
financial and managerial reporting techniques and systems, or a close relationship between accounting and taxation.

Professional organizations should therefore be ready to assist such businesses in improving their functioning with respect to these areas. A development of local SMPs that would be able to provide tailored services to SMEs would be helpful and necessary, and both professionals and professional bodies should adapt to such demands, as SMEs face economic, regulatory, social, and cultural pressures that may impact their utilization of accounting information and advice (IFAC, 2016). Following a review of recent literature, the IFAC (2016) study finds that SMEs' demand for business advice from SMPs is influenced by the company's size, debt, age, growth, available resources and environment-related factors (i.e., economic conditions, including regulations, and competition), while the personal characteristics of the SME owner-manager (i.e., relationship, trust, and perceived value of services) moderate the impact of company- and environment-related factors on SMEs' demand for business advice. By necessity, local SMPs are better positioned than larger international firms to provide tailored advice to such SMEs, thus contributing to the development of the accounting profession in the region.

Additionally, other themes seem to be of much interest with respect to SMEs. With respect to the economic environment of such entities, the implementation to a larger extent of the so-called 'SBA (Small Business Act) second chance principle' is called for by the EU (European Commission, 2016), to prevent bankruptcies and remove unsurmountable obstacles by honest entrepreneurs in starting a new business after a bankruptcy. In this respect, such services can and should be offered to SMEs by SMPs, thus expanding the services offered by such entities and offering them better survival and growth opportunities.

Moreover, the IFRS for SMEs seems to continue to be a hot topic in many jurisdictions around the world. A very recent example is Gassen (2017). By interviewing leading accounting experts from 24 jurisdictions around the globe, Gassen (2017) finds variations across the sample with respect to the adoption process, the benefits and perceptions of stakeholders regarding the IFRS for SMEs. The standard adds to the already complicated reporting environment of SMEs, and continues to play a significant role in setting the reporting stage of such entities. Researchers around the world should continue to embrace this research opportunity to make good use of differences across jurisdictions where the standard was adopted or permitted (such as South Africa) or not (such as Australia).

Connected to SMEs reporting, Accounting in Europe has just released a special issue (vol. 14(1-2)) dedicated to the role of IFRS in the completion of in the completion of National Accounting Rules applicable to large 'non-listed in a regulated market' non-financial undertakings trading for gain in 25 European countries following the recent implementation of the new European Accounting 
Directive 2013/34/EU. Variation across the sample was found, and a taxonomy of European accounting systems as strong equity/commercially driven versus weak equity/government driven/tax-dominated systems was created (André, 2017), indicating future research opportunities for researchers who can study the implications within and across countries and regions.

Not lastly, themes such as integrated reporting, sustainable reporting, or the adoption of techniques usually used by larger entities are of concern for practitioners and academics around the world (such as ACCA, CIMA, IFAC, or Global Reporting Initiative). Academics should continue to work with both professional bodies and SMEs to understand their particular needs, adoption or adaption process, and contrast them with the case of larger entities, thus uncovering interesting insights particular to such entities.

We would finally like to congratulate the contributing authors and to thank them for their efforts in creating this special issue. The reviewers, who are less visible but equally important, have also greatly contributed their skills and knowledge to selecting and strengthening the papers presented here. We believe that the final product offers important insights into the international diversity of accounting that can be exploited by accounting researchers, professional bodies and professionals in the future, nationally, regionally and internationally.

\section{References}

Ahrend, R. \& Martins, J.O. (2003) "Creative Destruction or Destructive Perpetuation: The Role of Large State-owned Enterprises and SMEs in Romania During Transition”, Post-Communist Economies, vol. 15(3): 331356

Albu, C.N., Albu, N., Fekete Pali-Pista, S., Gîrbină, M.M., Kardes Selimoglu, S., Kovacs, D.M., Lukacs, J., Mohl, G., Mullerova, L., Pasekova, M., PoroyArsoy, A., Sipahi, B. \& Strouhal, J. (2013) "Implementation of IFRS for SMEs in Emerging Economies: Stakeholder Perceptions in the Czech Republic, Hungary, Romania and Turkey”, Journal of International Financial Management \& Accounting, vol. 24(2): 140-175

American Institute of Certified Public Accountants (AICPA) (2013) "Financial Reporting Framework for Small- and Medium-Sized Entities”, available online at

http://www.aicpa.org/InterestAreas/FRC/AccountingFinancialReporting/PCF R/DownloadableDocuments/FRF-SME/FRF-SMEs-Framework.PDF

Andersén, J. \& Samuelsson, J. (2016) "Resource organization and firm performance: How entrepreneurial orientation and management accounting influence the profitability of growing and non-growing SMEs", International Journal of Entrepreneurial Behavior \& Research, vol. 22(4): 466 - 484 
André, P. (2017) "The Role and Current Status of IFRS in the Completion of National Accounting Rules - Evidence from European Countries", Accounting in Europe, vol. 14(1-2): 1-12

Association of Chartered Certified Accountants (ACCA) (2012) "SME internationalization in central and eastern Europe”, available online at http://www.accaglobal.com/content/dam/acca/global/PDF-technical/smallbusiness/pol-tp-sicee.pdf

Association of Chartered Certified Accountants (ACCA) (2015) "Governance for all: the implementation challenge for SMEs", available online at http://www.accaglobal.com/content/dam/acca/global/PDF-technical/smallbusiness/ea-governance-for-all.pdf

Chartered Institute of Management Accountants (CIMA) (2013) "Management Accounting Practices of (UK) Small-Medium-Sized Enterprises (SMEs). Improving SME performance through Management Accounting Education”, vol. 9(4), available online at

http://www.cimaglobal.com/Documents/Thought_leadership_docs/Managem ent\%20and\%20financial\%20accounting/ManagementAccountingPracticesOf Small-Medium-SizedEnterprises.pdf

Chau, F., Dosmukhambetova, G.B. \& Kallinterakis, V. (2013) "International Financial Reporting Standards and noise trading: Evidence from Central and Eastern European countries”, Journal of Applied Accounting Research, vol. 14(1): 37-53

Deaconu, A. \& Cuzdriorean, D.D. (2016) "'On the tax-accounting linkage in the European emerging context", Journal of Accounting in Emerging Economies, vol. 6(3): 206-231

Del Baldo 2 M. (2014) "Is it time for integrated reporting in small and mediumsized enterprises? Reflections on an Italian experience", pp. 183-209, Chapter in Idowu, S.O., Frederiksen, C.S., Mermod, A.Y., Nielsen, M.E.J. (Eds.) Corporate Social Responsibility and Governance. Theory and Practice, Series: CSR, Sustainability, Ethics \& Governance, ISBN 978-3319-10908-4, Heidelberg: Springer-Verlag

Directive 2013/34/EU of the European Parliament and of the Council on the annual financial statements, consolidated financial statements and related reports of certain types of undertakings, Official Journal of the European Union, L $182 / 19$

European Commission (2008) “Think Small First”. A “Small Business Act” for Europe, available online at http://eur-lex.europa.eu/legal-content/EN/ TXT/PDF/?uri=CELEX:52008DC0394\&from=EN

European Commission (2016) Annual Report on European SMEs 2015/2016, available online at http://ec.europa.eu/growth/smes/business-friendlyenvironment/performance-review-2016_en\#annual-report

Gassen, J. (2017) "The Effect of IFRS for SMEs on the Financial Reporting Environment of Private Firms: An Exploratory Interview Study” (March 29, 2017), Accounting and Business Research (Forthcoming), available online at SSRN: https://ssrn.com/abstract=2942923 
Global Reporting Initiative (2014) Ready to Report? Introducing Sustainability Reporting for SMEs, available online at https://www.globalreporting.org/ resourcelibrary/Ready-to-Report-SME-booklet-online.pdf

Institute of Chartered Accountants in England and Wales (ICAEW) (2015) "SME accounting requirements: basing policy on evidence. Public policy paper. Information for better markets initiative”, available online at https://www.icaew.com/ /media/corporate/files/technical/financial\%20report ing/information\%20for\%20better\%20markets/sme\%20accounting\%20requir ements\%20final.ashx

International Federation of Accountants (IFAC) (2016) “The Role of Small and Medium Practices in Providing Business Support to Small- and Mediumsized Enterprises”, available online at https://www.ifac.org/publicationsresources/role-small-and-medium-practices-providing-business-supportsmall-and-medium-s

Ismail, N.A. \& King, M. (2007) "Factors influencing the alignment of accounting information systems in small and medium sized Malaysian manufacturing firms”, Journal of Information Systems and Small Business, vol. 1(1-2): 1-20

Kaya, D. \& Koch, M. (2015) "Countries' adoption of the International Financial Reporting Standard for Small and Medium-sized Entities (IFRS for SMEs) early empirical evidence”, Accounting and Business Research, vol. 45(1): 93-120

Meyer, K.E. \& Peng, M.W. (2005) "Probing theoretically into Central and Eastern Europe: transactions, resources, and institutions”, Journal of International Business Studies, vol. 36(6): 600-621

Perera, D. \& Chand. P (2015) "Issues in the adoption of international financial reporting standards (IFRS) for small and medium-sized enterprises (SMES)", Advances in Accounting, vol. 31(1): 165-178

Pissarides, F. (1999) "Is lack of funds the main obstacle to growth? EBRD's experience with small- and medium-sized businesses in Central and Eastern Europe”, Journal of Business Venturing, vol. 14(5-6): 519-539

Stoian, M.C., Rialp, A., Rialp, J. \& Jarvis, R. (2016) "Internationalisation of Central and Eastern European small firms: Institutions, resources and networks", Journal of Small Business and Enterprise Development, vol. 23(1): 105-121

Talpas, L. (2016) "The Theoretical Bases for the Preparation of Financial Statements for SMEs: the case of Estonia”, PhD thesis, Tallin University of Technology, available online at https://audiitorkogu.ee/uploads/D_Liis\%20Talpas.pdf

Tatoglu, E., Bayraktar, E., Golgeci, I., Koh, S.C.L., Demirbag, M. \& Zaim, S. (2016) "How do supply chain management and information systems practices influence operational performance? Evidence from emerging country SMEs", International Journal of Logistics Research and Applications, vol. 19(3): 181-199

Vander Bauwhede, H., De Meyere, M. \& Van Cauwenberge, P. (2015) "Financial reporting quality and the cost of debt of SMEs", Small Business Economics, vol. 45(1): 149-164 